\title{
Evaluation of Unsaponified Petroleum Ether Extract of Lantana camara L. leaves for Antioxidant Activity and Oxidative Stability
}

\author{
Patil Shriniwas Pramod ${ }^{1 \star}$, Kumbhar Subhash Trimbakrao², Ambhore Vanita ${ }^{3}$ \\ 1'Department of Pharmacognosy, SCES's Indira College of Pharmacy, Pune, INDIA. \\ 2Department of Pharmacology,SCES's Indira College of Pharmacy, Pune, INDIA. \\ ${ }^{3}$ Padm. Dr. D. Y. Patil Institute of Pharmaceutical Sciences and Research, Pimpri, Pune, INDIA.
}

\begin{abstract}
Background: Lantana camara L. leaves have been traditionally claimed to be used in treatment of different illnesses. Leaves are rich in lower terpenes in the form of essential oil, however they also contain lipids like waxes. Both classes, lipids and terpenes are soluble in petroleum ether, but only lipids can be saponified, not terpenes. Aim: The present study was aimed towards preparation of unsaponified terpene-rich extract of L. camara L. leaves; its assessment for anti-oxidant activity and capacity to impart oxidative stability. Methods: In order to remove lipids and retain terpenes, in present study, petroleum ether extract of Lantana camara L. leaves was saponified using aqueous potassium hydroxide and unsaponified matter was standardized using $\beta$-caryophyllene as marker; screened for anti-oxidant activity, using DPPH radical scavenging model and estimated for its capacity to impart oxidative stability using Rancimat test. Results: Tested extract showed considerable antioxidant activity (IC ${ }_{50}$ value: $13 \mu \mathrm{g} / \mathrm{ml}$ ) and imparts $74.83 \%$ protection against oxidation as compared to standards used. Conclusion: Lipids can be removed by saponification and thereby, petroleum ether extract can be made rich in terpenes. This unsaponified petroleum ether extract of $L$. camara L. leaves shows better antioxidant results as compared to petroleum ether extract and comparable with standards used.
\end{abstract}

Key words: Lantana camara L., Terpenes and Tepenoids, DPPH Radical Scavenging Activity, Rancimat Test, Unsaponified petroleum ether extract.

\section{INTRODUCTION}

Lantana camara L. (Verbenaceae) is the notorious but ornamental weed, commonly known as red sage or wild sage. It is native to tropical, subtropical and temperate regions. ${ }^{1}$ In different parts of world, L. camara L. leaves are used for treatment of different diseases. In Nigeria and Senegal L. camara L. leaf infusions are used in treatment of cough, colds, asthma and pyrexia, ${ }^{2}$ in West Africa the leaves are used as diaphoretic, stimulant, and treatment of jaundice and rheumatism $^{3}$ while, in Central and South America and Ghana L. camara L. leaves along with flowers have been used against fever, influenza and stomach-ache sores, chicken pox, measles and high blood pres- sure. ${ }^{4}$ Leaves are rich in essential oil which showed antimicrobial potential, ${ }^{5-6}$ allelopathic property, ${ }^{7}$ anti-inflammatory activity, ${ }^{8}$ larvicidal efficacy against Aedes larvae.

L. camara L. leaves are simple, opposite, petiolate, ovate, 5 to $8 \mathrm{~cm}$ in length, 2 to $4 \mathrm{~cm}$ in width, crenate, hairy acute, surface rugosely reticulate, pubescent, petiole usually curved or bent, highly pubescent and reported to contain pentacyclic triterpenoids with carboxylic acid group; steroids, flavonoid aglycones, iridoids and some polyphenolics Table 1 however essential oil obtained from its leaves is rich in monoterpenes and sesquiterpenes hydrocarbons Table 2.

All organisms utilize oxygen and thereby generate Reactive oxygen species (ROS). ${ }^{31}$ However, excessive ROS production leads
Submission Date: 05-02-2017; Revision Date: 18-03-2017; Accepted Date: 30-03-2017

DOI: 10.5530/ijper.51.4.102 Correspondence: Mr. Patil Shriniwas Pramod,

Assistant Professor, Department of Pharmacognosy, SCES's Indira College of Pharmacy, Pune, INDIA. Address: C/o. Mr. R. N. Bhole, 4, 'Kalidas' Chamber, Dhake Colony, Jalgaon 425 001, Maharashtra, INDIA. Tel: 09403570177;

E-mail: patilsp111@gmail. com

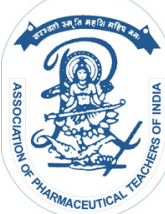

www.ijper.org 
to oxidative stress by overcoming cellular antioxidant defenses. ${ }^{32}$ These free radicals are responsible for causing a large number of diseases including cancer. ${ }^{33}$ cardiovascular disease. ${ }^{34}$ neural disorders, ${ }^{35}$ Alzheimer's disease, ${ }^{36}$ mild cognitive impairment, ${ }^{37}$ Parkinson's disease, ${ }^{38}$ alcohol induced liver disease, ${ }^{39}$ ulcerative colitis, ${ }^{40}$ aging $^{41}$ and atherosclerosis. ${ }^{42}$ Antioxidants are chemical entities preventing these oxidation damage and they can be divided into two main categories: enzymatic and nonenzymatic. Enzymatic antioxidants (examples:superoxide dismutases, catalase and glutathione peroxidases.) react with reactive species and are subsequently recycled. Non-enzymatic antioxidants interact with radical species and they are consumed during the reaction. Nonenzymatic antioxidants can be divided into hydrophilic (examples: glutathione, ascorbate and uric acid) and hydrophobic (examples: $\alpha$-tocopherol, carotenoids, and ubiquinol-10) antioxidants. ${ }^{43}$

Rao et al. studied in-vitro antioxidant potential of aqueous extract of $L$. camara $\mathrm{L},{ }^{44}$ leaves while Badakhshan et al. evaluated antioxidant activity of methanolic extract of various parts of $L$. camara $L$. and found that methanolic leaf extract was more effective that other parts. ${ }^{45}$ Few researchers have obtained essential oil from leaves; analysed it for phytochemicals present and evaluated its antioxidant activity. ${ }^{46,47}$ The present study was aimed at phytochemical screening and evaluation of antioxidant potential of unsaponified petroleum ether (USPE) extract of L. camara L. leaves.

\section{MATERIALS AND METHODS}

\section{Chemical}

Few consumables, 1,1-diphenyl-2-picrylhydrazyl (DPPH, >95\%) and Butyrate hydroxyl toluene (BHT, $>99 \%$ ) were purchased from Sigma-Aldrich (Bangalore, India) while, ascorbic acid (Vitamin C, >99\%), potassium hydroxide $(\mathrm{KOH})$ were procured from Loba Chemie Pvt. Ltd. India. Analytical grade ethanol, ethyl acetate, petroleum ether were purchased from Analab Fine Chemicals- Mumbai. Sunflower oil was bought from local market, Pune.

\section{Plant material}

L. camara L. leaves Figure 1 A \& 1B were collected in September, 2016 from Medicinal Plant Garden of Padm. Dr. D. Y. Patil Institute of Pharmaceutical Sciences and Research, Pimpri and identified by morphology and microscopy; and standard description. Leaves were then dried under shade and pulverized in grinder.

\section{Extraction}

Dried powder of $L$. camara leaves $(10 \mathrm{~g})$ was extracted with Petroleum ether $(30 \mathrm{ml})$ at room temperature for $6 \mathrm{~h}$ with frequent shaking. It was then treated with 30 $\mathrm{ml}$ of warm $10 \%$ aqueous $\mathrm{KOH}$, shaken and polaritybased two layers were separated. Petroleum ether layer was then concentrated to dryness under reduced pressure to obtain sticky mass $(0.3 \mathrm{~g})$. It was then analysed phytochemically and used as unsaponified petroleum ether (USPE) extract for evaluation of anti-oxidant activity.

\section{Phytochemical Prospection}

Both petroleum ether (PE) extract and USPE extract were tested for the presence of different secondary metabolites (alkaloids, terpene, tannins, flavonoids). Test specific for each class of secondary metabolites was based on change in colour or formation of precipitate on addition of specific reagent. Further, based on colour reaction and TLC analysis, USPE extract was standardized using $\beta$-caryophyllene as marker compound by GLC.

\section{Thin Layer Chromatographic analysis}

Both PE extract and USPE extract were applied separately on a precoated silica gel $60 \mathrm{~F}_{254}$ TLC plate (E. Merck) of uniform thickness of $0.2 \mathrm{~mm}$. Plate was developed in the mobile phase Toluene: Ethyl acetate (93: 07) in a twin trough chamber to a distance of $8 \mathrm{~cm}$ and then visualized by spraying anisaldehyde-sulphuric acid reagent and heating at $105^{\circ} \mathrm{C}$ for 5 to $10 \mathrm{~min}$.

\section{Gas Liquid Chromatographic analysis}

After confirming the presence of $\beta$-Caryophyllene in USPE by TLC, USPE was analyzed as test solution for quantification of $\beta$-Caryophyllene by GLC, using $\beta$-Caryophyllene as marker. Standard solutions $(0.2,0.4$, $0.6,0.8$ and $1.0 \mu \mathrm{l} / \mathrm{ml}$ ) of $\beta$-Caryophyllene were prepared in petroleum ether. About $1 \mu \mathrm{l}$ each of the standard and the test solutions were injected to the Agilent GC instrument with nitrogen as carrier gas at flow rate of 1 $\mathrm{ml} / \mathrm{min}$ at $250{ }^{\circ} \mathrm{C}$. It has HP-5 $(5 \%$ Phenyl methylsiloxane) capillary column $(30 \mathrm{~m} \times 320 \mu \mathrm{m} \times 0.25 \mu \mathrm{m})$ and flame ionization detector. Content of $\beta$-Caryophyllene was calculated from the integrated areas of the peak corresponding to that of $\beta$-Caryophyllene. The estimation was carried out in triplicate.

\section{Radical-scavenging activity-DPPH assay}

The antioxidant activity of USPE extract was evaluated by monitoring their ability in quenching the stable free radical DPPH. ${ }^{46}$ Stock ethanolic solution of DPPH (100 $\mu \mathrm{M}$ ) was prepared and its $1.5 \mathrm{ml}$ was added to $2.5 \mathrm{ml}$ of petroleum ether solutions of different concentrations 
of USPE extract $(10,20,40 \mu \mathrm{g} / \mathrm{ml})$ and incubated for 30 min in dark at room temperature. Then absorbance of samples was measured at $518 \mathrm{~nm}$ by spectrophotometer (Shimadzu UV-1800 UV-Vis spectrophotometer). Blank reading was previously noted and Ascorbic acid was used as standard. Percent Inhibition was calculated using a formula:

$\%$ Inhibition $=100-\left[\left(\mathrm{Abs}_{\text {sample }}-\mathrm{Abs}_{\text {blank }}\right) \times 100 /\right.$ Abs $\left.{ }_{\text {control }}\right]$

Where $\mathrm{Abs}_{\text {sample }}$ is the absorbance obtained in the presence of USPE extract concentrations and Abs control $_{\text {is }}$ that obtained in the absence of extracts. The concentration necessary to inhibit 50\% radical formation, inhibitory capacity $\mathrm{IC}_{50}$ were obtained by extrapolating the graph obtained by plotting the $\%$ inhibition versus different concentrations of USPE extracts, determined in triplicate.

\section{Rancimat method}

Ability of USPE extract to impart oxidative stability to oil was evaluated by Rancimat method ${ }^{48}$ (EN 14112) with modifications. Samples of sunflower oil (3.5 g) with $2.5 \mathrm{ml}$ of petroleum ether solutions containing different concentrations $(10,20$ and $40 \mu \mathrm{g} / \mathrm{ml})$ of USPE extract were heated at $110^{\circ} \mathrm{C}$ for $6 \mathrm{~h}$ (Induction period for sunflower oil). Butyrate hydroxyl toluene (BHT) was used as standard. Then, at the same time, Fourier Transformed Infra Red (FTIR) spectrums of samples were recorded.

\section{Statistical analysis}

Data of evaluation of antioxidant activity i.e. effect of different concentrations on DPPH free radicals were expressed as mean \pm S.D.

\section{RESULT}

\section{Phytochemical Prospection}

Phytochemical tests indicated the presence of sterols, lipids, terpenes in PE extract while sterols and lipids were found absent in USPE extract. TLC analysis resulted in same observations where PE showed green, blue, violet, brown bands while USPE had only violet and pink bands. Based on reference finding and TLC analysis, it was confirmed that USPE contains only terpenes and $\beta$-caryophyllene was one of them.

Further, $\beta$-caryophyllene quantification by GLC generated plot Figure 2 indicated $\beta$-caryophyllene content and GLC profile of USPE. Retention time of $\beta$-caryophyllene was $16.7 \mathrm{~min}$. Area of the peak corresponding to $\beta$-caryophyllene in USPE was used in calculations for determination $\beta$-caryophyllene content, which on triplicate analysis, was found to be ranging between 31.01 to $31.8 \%$.

\section{DPPH radical-scavenging activity}

The results of DPPH radical-scavenging activity of USPE extract of $L$. camara L. leaves have been reported in Figure 3. It was found that there is increase in \% inhibition on increase in concentration of both Ascorbic acid and USPE extract. Sample with higher concentration of USPE extract (40 $\mu \mathrm{g} / \mathrm{ml})$ had highest $93.67 \%$

Table 1: Chemical composition of L. camara leaves

\begin{tabular}{|c|c|}
\hline Class & Phyto-constituents \\
\hline Pentacyclictriterpenoids & $\begin{array}{c}\text { Lantadene } \mathrm{A},{ }^{10} \text { Lantadene } \\
\mathrm{B} ;{ }^{10} \text { Lantadene } \mathrm{C},{ }^{11} \text { Lantadene } \\
\mathrm{D},{ }^{12} \text { Icterogenin, },{ }^{13} \text { Camarinic } \\
\text { acid, },{ }^{14} \text { Camaric acid, },{ }^{14} \text { Oleanolic } \\
\text { acid, }{ }^{14} \text { Pomolic acid, }{ }^{14} \text { Camarilic } \\
\text { acid, }{ }^{15} \text { Camaricinic acid, }{ }^{15} \text { Lantanoic } \\
\text { acid, },{ }^{16} \text { Lantanolic acid, }{ }^{17} \text { Lantic } \\
\text { acid, }{ }^{18,19} \text { Lantanilic acid, }{ }^{20} \beta, \beta- \\
\text { Dimethylacryloyl ester of lantanilic } \\
\text { acid, }{ }^{20} 3,24 \text { - Dioxy-urs-12-en- } \\
\text { 28-oic acid }{ }^{21}, \text { Lantabetulic acid, }{ }^{22} \\
\text { lancamarolide }{ }^{23}\end{array}$ \\
\hline Steroid & Lancamarone $^{24}$ \\
\hline Iridoid glycosides & $\begin{array}{l}\text { Theveside }{ }^{25} \text { Camaraside }{ }^{26} \\
\text { Martynoside }{ }^{1} \\
\text { Derhamnosylverbascoside, }{ }^{27} \\
\text { Isonuomioside } \mathrm{A}^{27}\end{array}$ \\
\hline Flavonoid aglycones ${ }^{28}$ & $\begin{array}{l}\text { 3-methoxy quercetin, } 3 \text {, } \\
\text { 7- dimethoxyquercetin, 3,7,4'- } \\
\text { trimethoxyquercetin }\end{array}$ \\
\hline Polyphenolics ${ }^{29}$ & $\begin{array}{c}\text { Salicylic acid, Gentisic acid, } \\
\text { B-resorcylic acid, Coumarin, Ferulic } \\
\text { acid, } p \text {-Hydroxybenzoic acid, } \\
\text { 6-Methyl coumarin }\end{array}$ \\
\hline
\end{tabular}

Table 2: Chemical composition of essential oil obtained from $L$. camara leaves ${ }^{30}$

\begin{tabular}{|c|c|}
\hline Class & Phyto-constituents \\
\hline \multirow{4}{*}{ Monoterpenes hydrocarbons } & Sabinene \\
\cline { 2 - 2 } & a-pinene \\
\cline { 2 - 2 } Oxygenated monoterpenes & -terpinene \\
\cline { 2 - 2 } & E)-citral \\
\cline { 2 - 2 } & $(\mathrm{Z})$-citral \\
\hline \multirow{4}{*}{ Sesquiterpenes hydrocarbons } & 1,8 cineole \\
\cline { 2 - 2 } & trans-caryophyllene, \\
\cline { 2 - 2 } & $\beta$-caryophyllene \\
\cline { 2 - 2 } & bicyclogermacrene, \\
\cline { 2 - 2 } & a-curcumene \\
\hline
\end{tabular}


inhibition. $\mathrm{IC}_{50}$ value for USPE extract $(13 \mu \mathrm{g} / \mathrm{ml})$ was found to be comparable with that of Ascorbic acid (11 $\mu \mathrm{g} / \mathrm{ml})$.

\section{Rancimat method}

FTIR spectra for sunflower oil before oxidation was recorded and superimposed by those recorded for samples containing different doses of extracts and for sample with BHT after heating at $110^{\circ} \mathrm{C}$ for $6 \mathrm{~h}$ have been shown in Figure 4. In each spectra, carbonyl band was obtained at $1760 \mathrm{~cm}^{-1}$. Their area under curve (AUC) was used for quantitative estimation of the oxidation level. Table 3 shows AUC of carbonyl bands of spectrum of all samples.

Induction period of sunflower oil was estimated at around $6 \mathrm{~h}$. The highest oxidative stability in sunflower roil was exhibited in sample containing highest dose i.e. $40 \mu \mathrm{g} / \mathrm{ml}$ of USPE extract. The extent of oxidation changes monitored in all examined samples of sunflower oils containing USPE has proved that it imparts dose dependent oxidative stability.

\section{DISCUSSION}

There are various phytoconstituents of different classes present in leaves of L. camara L. Out of these, oils, fats, sterols, terpenes are soluble in non-polar solvent like petroleum ether. Accordingly, petroleum ether extract showed presence of sterols, lipids and terpenes. In the present study, saponification of petroleum ether extract was carried out. This lead to saponification of oils and fats which were solubilized in petroleum ether extract to their corresponding Potassium salts. At the same time, saponification had no effect on other petroleum ether soluble compounds like terpenes. Ultimately, USPE extract showed presence of only terpenes. This is again justified by $\beta$-caryophyllene content of USPE extract (31.01 to $31.8 \%$.). Different researchers have reported different $\beta$-caryophyllene content in of essential oil isolated from L. camara L. leaves. Sonibare et al. found that its content as $8.9 \%{ }^{5}$; Zoubiri et al. found it is $35.70 \% ;{ }^{49}$ Alitonou et al. estimated it as $18.5 \%{ }^{50}$ while Randrianalijaona et al. found it is $30.85 \% \cdot{ }^{51}$ However, Unnithan et al. ${ }^{2}$ found $\beta$-caryophyllene content of petroleum ether extract of $L$. camara $L$. leaves to be $0.06 \%$. These findings indicates that saponification of petroleum ether extract of $L$. camara L. leaves removed fats and oils contents of leaves and retained terpenes in unsaponified matter.

USPE extract of L. camara L. leaves showed DPPH radial scavenging activity comparable to standard Ascorbic acid. DPPH exist as free radical stabilized by delo-

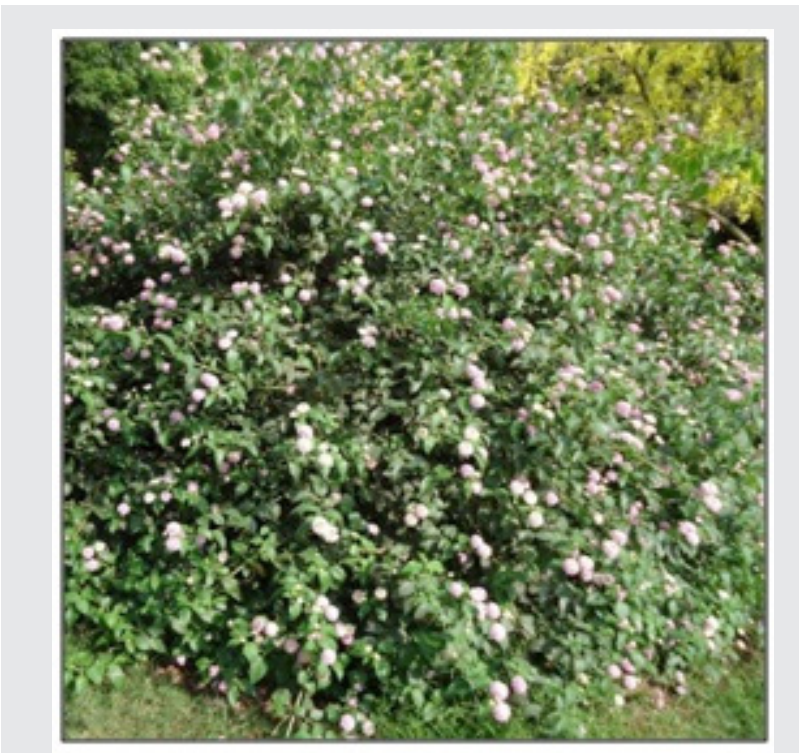

Figure 1(A): Lantana camara L. a) Habitat.

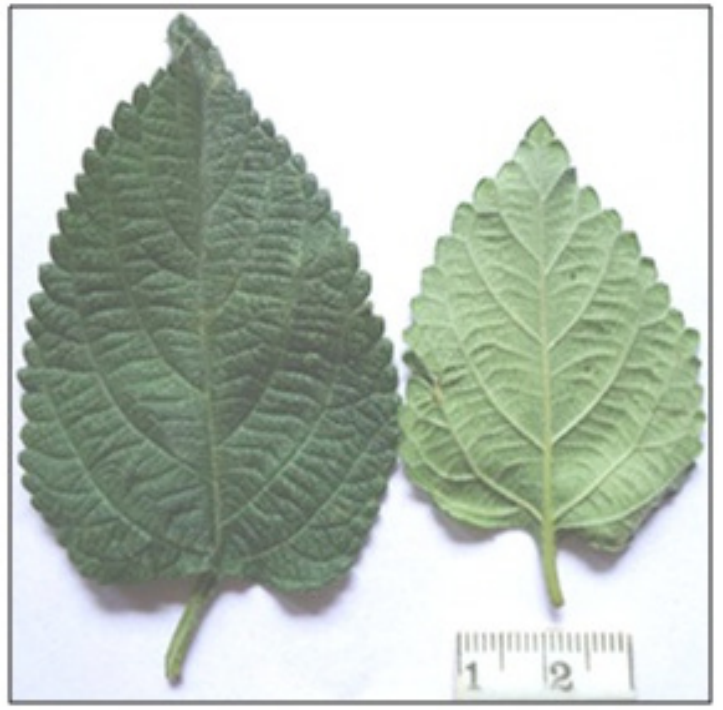

Figure 1(B): Lantana camara L. b) Leaves.

Table 3: Area under curve (AUC) of Carbonyl band

\begin{tabular}{|c|c|c|}
\hline Sample & $\begin{array}{c}\text { AUC of carbonyl band } \\
\text { at } \mathbf{1 7 6 0} \mathbf{~ m}^{-1}\end{array}$ & \% Protection \\
\hline BHT & 298 & 84.66 \\
\hline USPE $(40 \mu \mathrm{g} / \mathrm{ml})$ & 489 & 74.83 \\
\hline USPE $(20 \mu \mathrm{g} / \mathrm{ml})$ & 634 & 67.37 \\
\hline USPE $(10 \mu \mathrm{g} / \mathrm{ml})$ & 1052 & 45.86 \\
\hline Without USPE & 1943 & 0.00 \\
\hline
\end{tabular}


calization of unpaired electron over the whole DPPH radical. This imparts violet colour, in ethanol which has absorbance maximum at $518 \mathrm{~nm}$. As it receives hydrogen atom from anti-oxidant compound, it gets reduced to colourless DPPH hence absorbance of DPPH-antioxidant solution decreases. ${ }^{53} \mathrm{IC}_{50}$ values of both Ascorbic acid and USPE extract indicates that nearly same quantity of both Ascorbic acid and USPE extract is sufficient to make $50 \%$ of DPPH free radicals to colorless DPPH.
Results of Rancimat tests were also found to be dosedependent in imparting oxidative stability to sunflower oil. In sample containing no USPE, oxidative stability was imparted by naturally occurring range of antioxidants such as tocopherols, phenolics and sterols. ${ }^{54}$ In Rancimat test, it was important that antioxidant to be tested or added should be soluble in sunflower oil. Hence, Ascorbic acid, a standard used in evaluation of DPPH radical scavenging activity was replaced by BHT as it is soluble in sunflower oil. Area under curve (AUC)

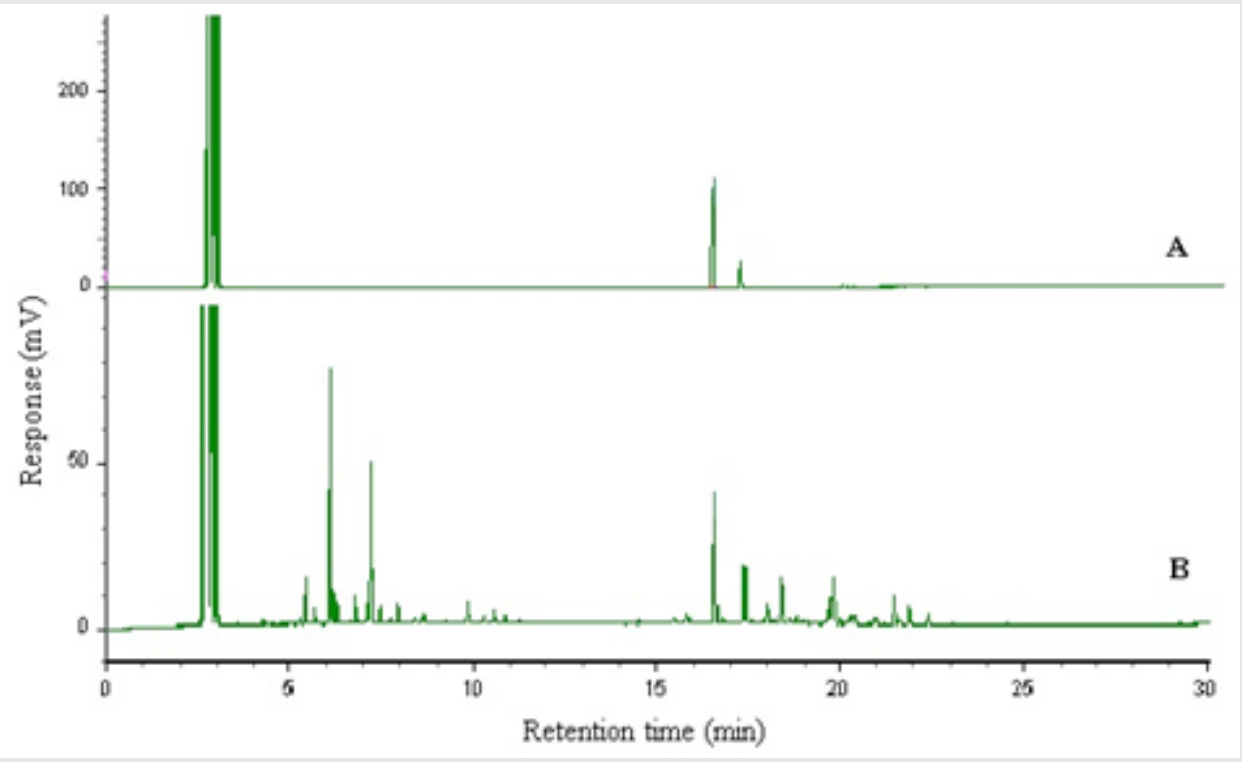

Figure 2: GLC fingerprint profile A. $\beta$-Caryophyllene standard; B. Test solution.

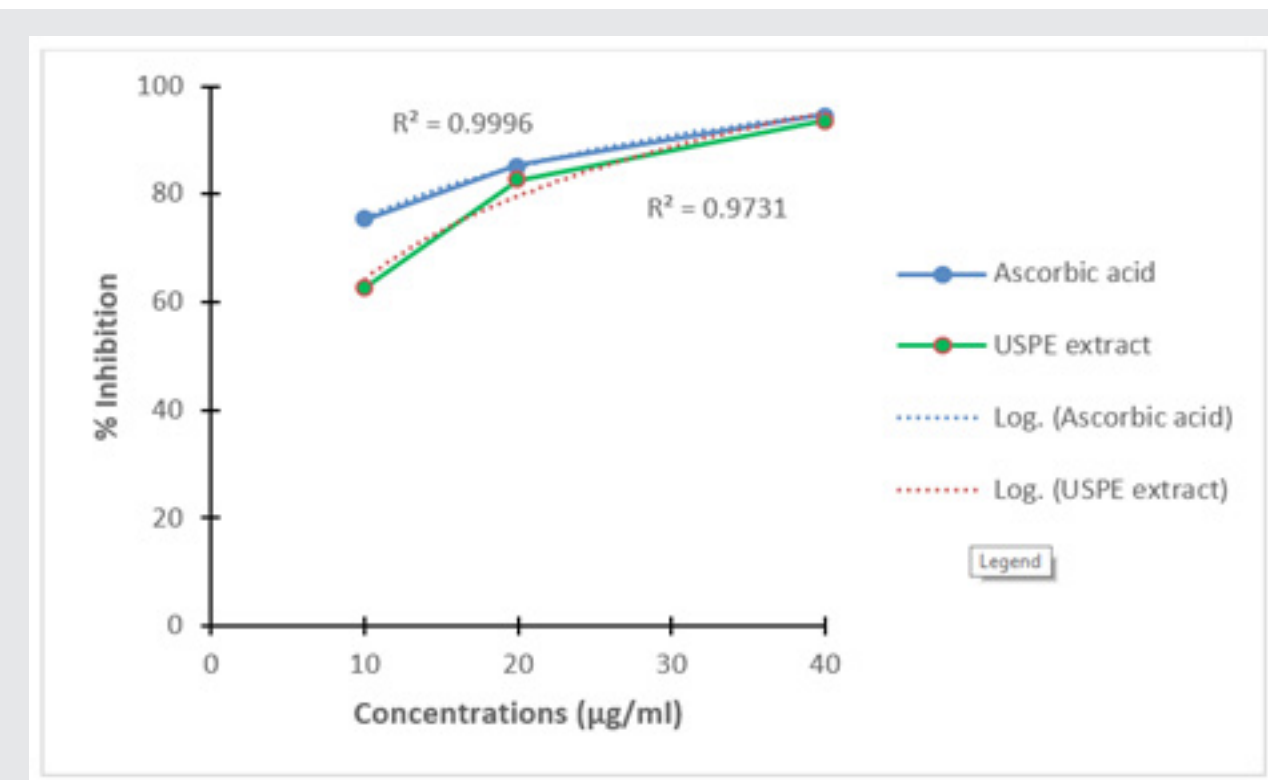

Figure 3: Graph of Concentrations $(\mu \mathrm{g} / \mathrm{ml})$ of USPE extract versus $\%$ Inhibition indicating effect of different concentrations on DPPH free radicals. 


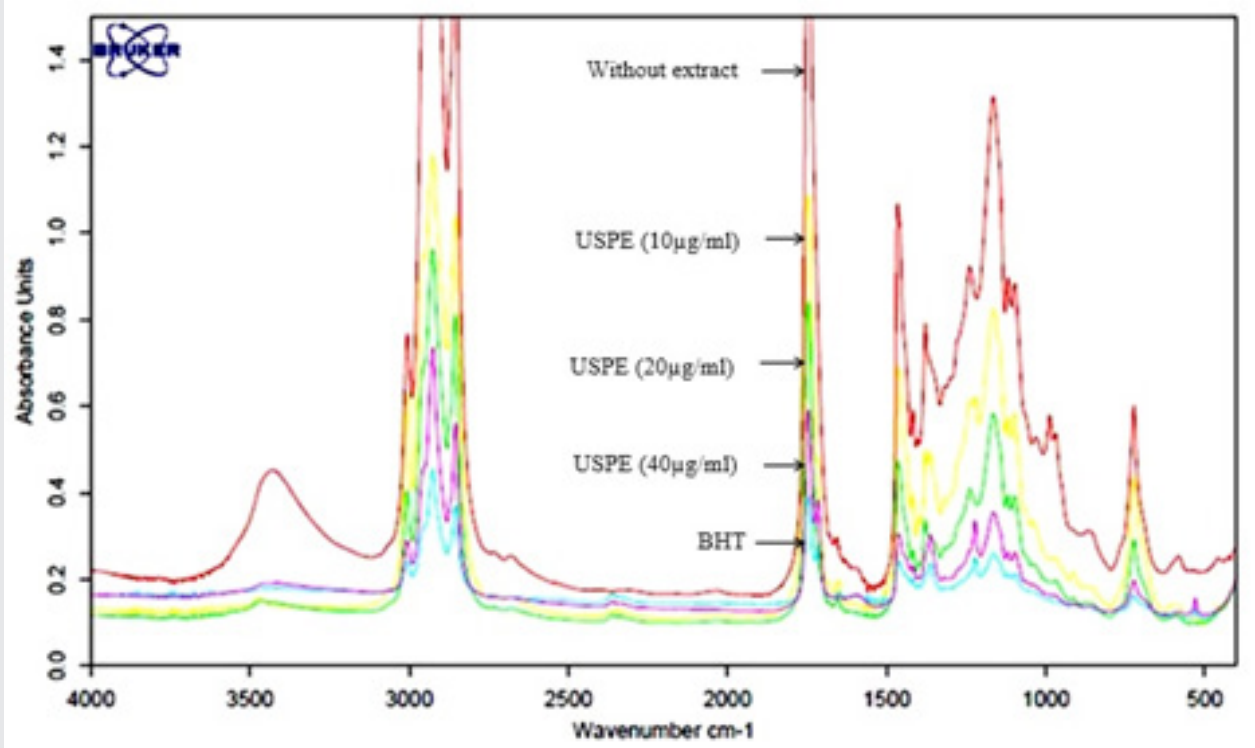

Figure 4: FTIR spectrum of different samples of sunflower oil after induction period without test extract and standard, with different concentrations of USPE extract and that with standard, BHT.

values indicate the extent of oxidation by formation of carbonyl bonds. Hence lesser the AUC value, lesser the extent of oxidation and higher the oxidative stability. Terpernes present in USPE extract may impart oxidative stability to sunflower oil.

\section{CONCLUSION}

In the present study, unsaponified petroleum ether extract (USPE) of $L$. camara L. leaves was tested for antioxidant activity and oxidative stability. Extraction was performed by simple cold maceration and saponifiable matter was separated. Unsaponified extract was then analyzed phytochemically and standardized using $\beta$-caryophyllene. Its DPPH radical scavenging activity was determined and oxidative stability was evaluated by modified Rancimat test. It was found that USPE extract has anti-oxidant potential and imparts oxidative stability to sunflower oil comparable to standards used i.e. Ascorbic acid and BHT. Based on these results, it could be noted that there is future scope for evaluation of USPE extract for in-vivo pharmacological activities exhibited by terpenes for research in phyto- pharmacology.

\section{ACKNOWLEDGEMENT}

We are thankful to Dr. (Mrs.) Anagha M. Joshi, Principal, Shree Chanakya Education Society's Indira College of Pharmacy Pune, India for providing lab facilities. We are also thankful to Dr. Deepawali Thanekar, Institute of Science, Mumbai and Ms. Sharwari Ghodke, Institute of Chemical Technology, Mumbai, India for helping us in literature survey.

\section{CONFLICT OF INTEREST}

We declare that we have no conflict of interest.

\section{ABBREVIATION}

DPPH: 1,1-diphenyl-2-picrylhydrazyl ( $\alpha, \alpha$-diphenyl- $\beta$ picrylhydrazyl); FTIR: Fourier Transformed Infra Red spectroscopy; AUC: Area Under Curve; USPE: Unsaponified petroleum ether; BHT: Butyrate hydroxyl toluene; GLC: Gas Liquid Chromatography; TLC: Thin Layer Chromatography.

\section{REFERENCES}

1. Ghisalberti EL. Review Lantana camara L. (Verbenaceae) Fitother. 2000;71:467-86. https://doi.org/10.1016/S0367-326X(00)00202-1.

2. Bever BO. Medicinal plants in tropical West Africa II. Plants acting on the nervous system. J Ethnopharmacol. 1983;7(1):1-93. https://doi. org/10.1016/0378-8741(83)90082-X : : https://doi.org/10.1016/03788741(83)90028-4.

3. Hedberg I, Hedberg O, Madati PJ, Mshigeni KE, Mshiu EN, Samuelsson G. Inventory of plants used in traditional medicine in Tanzania. Part III. Plants of the Families Papilionaceae vitaceae. J Ethnopharmacol. 1983;9(1):237-60. https://doi.org/10.1016/0378-8741(83)90034-X.

4. Hernandez T, Canales M, Avila JG, Duran A, Caballero J, Vivar AR de, et al. Ethnobotany and antibacterial activity of some plants used in traditional medicine of Zapotitlan de las Salinas, Puebla (Mexico). J Ethnopharmacol. 2003;88(2):181-8. https://doi.org/10.1016/S0378-8741(03)00213-7. 
5. Sonibare OO, Effiong I. Antimicrobial activity and cytotoxicity of essential oil of Lantana camara leaves from Nigeria. Afr J Biotechnol. 2008;7(15):261820.

6. Pattnaik S, Pattnaik B. A study of Lantana camara Linn. aromatic oil as an antimicrobial agent. Int Res J Pharm Sci. 2010;1(1):32-5.

7. Verdeguer M, Blázquez MA, Boira H. Phytotoxic effects of Lantana camara, Eucalyptus camaldulensis and Eriocephalusafricanus essential oils in weeds of Mediterranean summer crops. Bio chem Syst Ecol. 2009;37(4):362-9. https://doi.org/10.1016/j.bse.2009.06.003.

8. Benites J, Moiteiro C, Miguel G, Rojo L, Lopez J, Venancio F, et al. Composition and biological activity of the essential oil of Peruvian Lantana camara. J Chil Chem Soc. 2009;54(4):379-84. https://doi.org/10.4067/ S0717-97072009000400012.

9. Dua VK, Pandey AC, Dash AP. Adulticidal activity of essential oil of Lantana camara leaves against mosquitoes. Ind J Med Res. 2010;131:434-9. PMid:20418559.

10. Sharma OP, Sharma PD. Natural products of Lantana plant - the present and prospects. J Sci Ind Res. 1989;48(10):471-8.

11. Johns SR, Lamberton JA, Morton TC, Suares H, Willing RI. 22ß-[(S)-2Methylbutanoyloxy]-3- oxoolean-12-en-28-oic acid, a new constituent of Lantana camara. Aust J Chem. 1983;36(9):1895-902. https://doi.org/10.1071/ $\mathrm{CH} 9831895$.

12. Sharma OP, Dawra RK, Dandala R. A triterpenloid acid, Lantadene $D$ from Lantana camara var. aculeate. Phyto chem. 1990;29(12):3961-2. https://doi. org/10.1016/0031-9422(90)85377-R.

13. Hegnauer R. Chemotaxonomie der Pflanzen. 1973;6:673;793.

14. Siddiqui BS, Raza SM, Begum S, Siddiqui S, Firdous S. Pentacyclic Triterpenoids from Lantana camara. Phyto chem. 1995;38(3):681-85 https:// doi.org/10.1016/0031-9422(94)00691-I.

15. Begum S, Raza SM, Siddiqui BS, Siddiqui $S$. Triterpenoids from the aerial parts of Lantana camara. J Nat Prod. 1995;58(10):1570. https://doi. org/10.1021/np50124a014.

16. Barua AK, Roy S. The structure and stereochemistry of triterpene acid from Lantana camara. Phyto Chem. 1985;2(7):1607-8.

17. Barua AK, Chakrabarti TP, Dutta SP, Mukherjee DK, Das BC. Triterpenoids XXVII: The structure and Stereochemistry of lantanolic acid-a new triterpenoid from Lantana camara. Tetrahedron. 1971;27(6):1141-7. https:// doi.org/10.1016/S0040-4020(01)90861-0.

18. Barua AK, Chakrabarti P, Sanyal AK, Das BC. Triterpenoids XXXII. Structure of lantic acid: a new triterpene from Lantana camara. J Indian Chem Soc. 1969;46(1):100-1.

19. Barua AK, Chakrabarti P, Sanyal PK, Basu K, Nag, K. Tritrpenoids XL. Structure of lantic acid: a new triterpene from Lantana camara. J Indian Chem Soc 1972; 49: 1063-4.

20. Barua AK, Chakrabarti P, Chowdhury MK, Basak A, Basu BK. The structure and stereochemistry of lantanilic acid, the $\beta, \beta$-dimethylacryloyl ester of lantaninilic acid, isolated from Lantana camara. Phytochem. 1976;15(6):9879. https://doi.org/10.1016/S0031-9422(00)84386-1.

21. Yadav SB, Tripathi V. A new triterpenoid from Lantana camara. Fitother. 2003;74(3):320-1. https://doi.org/10.1016/S0367-326X(03)00034-0.

22. Hart NK, Lamberton JA, Sioumis AA, Suares H, Seawright AA. Triterpenes of toxic and non-toxic taxa of Lantana camara. Experientia. 1976;32(4):412-3. https://doi.org/10.1007/BF01920764; PMid:1269634.

23. Begum S, Ayub A, Siddiqui SB, Fayyaz S, Kazi F. Nematicidal Triterpenoids from Lantana camara. Chemi Bio Diver. 2015;12(9):1435-42.

24. Siddiqui BS, Raza SM, Begum S, Siddiqui S, Firdous S. Pentacyclic Triterpenoids from Lantana camara. Phyto chem. 1995;38(3):681-5. https:// doi.org/10.1016/0031-9422(94)00691-I.

25. Ford CW, Bendall MR. Identification of the iridoidglucosidetheveside in Lantana camara (Verbenaceae) and determination of its structure and stereochemistry by means of NMR. Aust J Chem. 1980;33(3):509-18. https:// doi.org/10.1071/CH9800509.

26. Mahato SB, Sahu NP, Roy SK, Sharma OP. Potential antitumor agents from Lantana camara: structures of flavonoid, and phenylpropanoid glycosides. Tetrahedron. 1994;50(31):9439-46. https://doi.org/10.1016/S00404020(01)85518-6.
27. Taoubi K, Fauvel MT, Gleye J, Moulis C, Fouraste I. Phenylpropanoid glycosides from Lantana camara and Lippiamultiflora. Planta Med. 1997;63(02):192-3. https://doi.org/10.1055/s-2006-957647 ; PMid:17252346.

28. Wollenweber E, Dorr M, Muniappan R, Siems K. Flavonoid aglycones and triterpenoids from the leaf exudate of Lantana camara and Lantana montevidensis. Biochem Syst Ecol. 1997;25(3):269-70. https://doi. org/10.1016/s0305-1978(96)00115-9.

29. Yi Z, Zhang M, Ling B, Xu D, Ye J. Inhibitory effects of Lantana camara and phenolic compounds from it on growth of Eichhorniacrassipes. Yingyong Shengtai Xuebao. 2006;17(9):1637-40. PMid:17147172.

30. Seth R, Mohan M, Singh P, Syed ZH, Gupta S, Bajpai I, et al. Chemical composition and antibacterial properties of the essential oil and extracts of Lantana camara Linn. From Uttarakhand (India). Asian Pac J Trop Biomed. 2012;S1:407-11. https://doi.org/10.1016/s2221-1691(12)60426-2.

31. Silva CG, Herdeiro RS, Mathias CJ, Panek AD, Silveira CS, Rodrigues VP, et al Evaluation of antioxidant activity of Brazilian plants. Pharm Res. 2005;52(3):229-33. https://doi.org/10.1016/j.phrs.2005.03.008 ; PMid:15896976.

32. Finkel T, Holbrook NJ. Oxidants, oxidative stress and the biology of ageing Nature. 2000;408(6809):239-47. https://doi.org/10.1038/35041687 ; PMid:11089981.

33. Kinnula VL, Crapo JD. Superoxide dismutases in malignant cells and human tumors. Free Radic Biol Med. 2004;36(6):718-44. https://doi.org/10.1016/j. freeradbiomed.2003.12.010; PMid:14990352.

34. Singh U, Jialal I. Oxidative stress and atherosclerosis. Pathophysiology. 2006;13(3):129-42. https://doi.org/10.1016/j.pathophys.2006.05.002 ; PMid:16757157.

35. Sas K, Robotka H, Toldi J, Vecsei L. Mitochondrial, metabolic disturbances, oxidative stress and kynurenine system, with focus on neurodegenerative disorders. J Neurol Sci. 2007;257:221-39. https://doi.org/10.1016/j. jns.2007.01.033; PMid:17462670.

36. Smith MA, Rottkamp CA, Nunomura A, Raina AK, Perry G. Oxidative stress in Alzheimer's disease. Biochim Biophys Acta. 2000;1502(1):139-44. https:// doi.org/10.1016/S0925-4439(00)00040-5.

37. Guidi I, Galimberti D, Lonati S, Novembrino C, Bamonti F, Tiriticco M, et al. Oxidative imbalance in patients with mild cognitive impairment and Alzheimer's disease. Neurobiol Aging. 2006;27:262-9. https://doi. org/10.1016/j.neurobiolaging.2005.01.001; PMid:16399211.

38. Bolton JL, Trush MA, Penning TM, Dryhurst G, Monks TJ. Role of quinones in toxicology. Chem Res Toxicol. 2000;13(3):135-60. https://doi.org/10.1021/ tx9902082 ; PMid:10725110.

39. Arteel GE. Oxidants and antioxidants in alcohol induced liver disease. Gastroenterol. 2003;124(3):778-90. https://doi.org/10.1053/gast.2003.50087 ; PMid:12612915.

40. Ramakrishna BS, Varghese R, Jayakumar S, Mathan M, Balasubramanian KA. Circulating antioxidants in ulcerative colitis and their relationship to disease severity and activity. J Gastroenterol Hepatol. 1997;12(7):490-4. https://doi.org/10.1111/j.1440-1746.1997.tb00471.x ; PMid:9257238.

41. Hyun DH, Hernandez JO, Mattson MP, de Cabo R. The plasma membrane redox system in aging. Aging Res Rev. 2006;5(2):209-20. https://doi. org/10.1016/j.arr.2006.03.005; PMid:16697277.

42. Upston JM, Kritharides $L$, Stocker $R$. The role of vitamin $E$ in atherosclerosis. Prog Lipid Res. 2003;42(5):405-22. https://doi.org/10.1016/S01637827(03)00024-9.

43. Boots AW, Haenen GRMM, Bast A. Health effects of quercetin: from antioxidant to nutraceutical. Eur J Pharmacol. 2008;585(2):325-37. https:// doi.org/10.1016/j.ejphar.2008.03.008; PMid:18417116.

44. Kalita S, Kumar G, Karthik L, Rao KVB. In vitro antioxidant and DNA damage inhibition activity of aqueous extract of Lantana camara L. (Verbenaceae) leaves. Asian Pac J Trop Biomed. 2012;2(3):S1675-9. https://doi.org/10.1016/ S2221-1691(12)60476-6.

45. Mahdi-Pour B, Jothy SL, Latha LY, Chen Y, Sasidharan S. Antioxidant activity of methanol extracts of different parts of Lantana camara. Asian Pac J Trop Biomed. 2012;2(12):960-5. https://doi.org/10.1016/S2221-1691(13)60007-6.

46. Sousa EO, Rocha JBT, Barros LM, Barros ARC, Costa JGM. Phytochemical characterization and in vitro antioxidant properties of Lantana camara L. and Lantana montevidensis Briq. Ind Crops Prod. 2013;43:517-22. https://doi. org/10.1016/j.indcrop.2012.07.058. 
47. Elansary HO, Salem MZM, Ashmawy NA, Yacout MM. Chemical Composition, Antibacterial and Antioxidant Activities of Leaves Essential Oils from Syzygium cumini L, Cupressuss empervirens L. And Lantana camara L. from Egypt. J Agric Sci. 2012;4(10):144.

48. Araújo SV, Rocha BS, Luna FMT, Rola EM Jr, Azevedo DCS, Cavalcante CL Jr. FTIR assessment of the oxidation process of castor oil FAME submitted to PetroOXY and Rancimat methods. Fuel Processing Technology. 2011;92(5):1152-5. https://doi.org/10.1016/j.fuproc.2010.12.026.

49. Zoubiri S, Baaliouamer A. GC and GC/MS analyses of the Algerian Lantana camara leaf essential oil: Effect against Sitophilus granaries adults. J Saudi Chem Soc. 2012;16(3):291-7. https://doi.org/10.1016/j.jscs.2011.01.013.

50. Alitonou G, Avlessi F, Bokossa I, Ahoussi E, Dangou J, Sohounhloe DCK. Composition Chimique et Activite Biologique de l'Huile Essesntielle de
Lantana camara L. Compte Rendue de Chimie. 2004;7(10):1101-5. https:// doi.org/10.1016/j.crci.2003.11.017.

51. Randrianalijaona, Ramanoelina PAR, Rasoarahona JRE, Gaydou EM. Seasonal and chemotype influences on the chemical composition of Lantana camara L. essential oils from Madagascar. Anal Chimica Acta. 2005;545(1):46-52 https://doi.org/10.1016/j.aca.2005.04.028.

52. Unnithan AR, Unnikrishnan G. Larvicidal bioassay of five tropical plants against Aedesaegypti. World J Pharm Res. 2015;4(10):2436-46.

53. Alam MN, Bristi NJ, Rafiquzzaman M. Review on in vivo and in vitro methods evaluationof antioxidant activity. Saudi Pharm J. 2013;21(2):143-52. https:// doi.org/10.1016/j.jsps.2012.05.002 ; PMid:24936134 PMCid:PMC4052538.

54. Marinova EM, Seizova KA, Totseva IR, Panayotova SS, Marekov IN Momchilova SM. Oxidative changes in some vegetable oils during heating at frying temperature. Bulg Chem Comm. 2012;44(1):57-63.

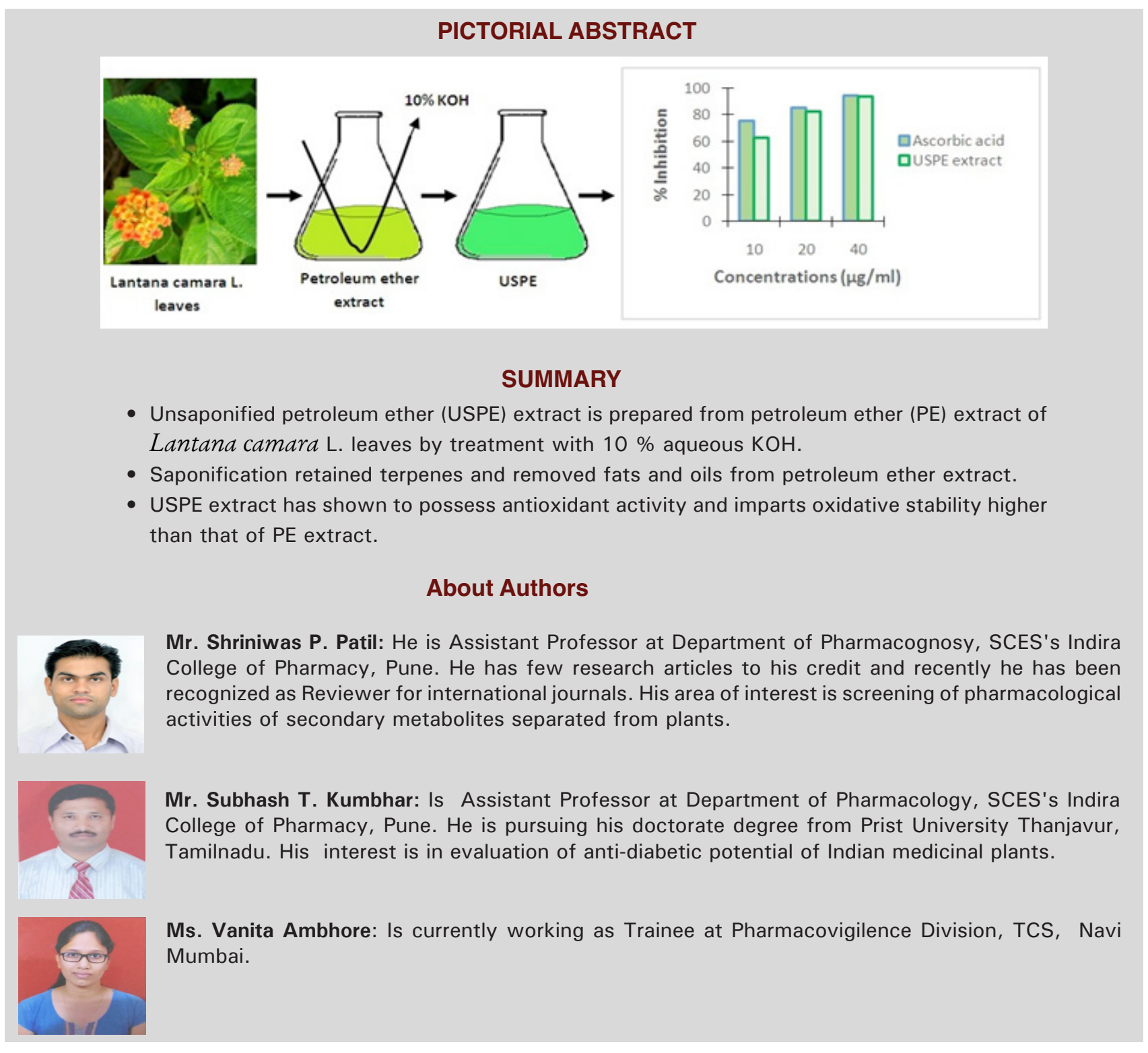

Cite this article: Pramod PS, Trimbakrao KS, Vanita A. Evaluation of Unsaponified Petroleum Ether Extract of Lantana camara L. leaves for Antioxidant Activity and Oxidative Stability. Indian Journal of Pharmaceutical Education and Research. 2017;51(4):692-9. 